University of Missouri, St. Louis

IRL@ UMSL

6-28-2015

\title{
Willful Understanding: Avicenna's Philosophy of Action and Theory of the Will
}

Jon McGinnis

University of Missouri-St. Louis, mcginnis@umsl.edu

Anthony Ruffus

Follow this and additional works at: https://irl.umsl.edu/philosophy-faculty

Part of the Philosophy Commons

\section{Recommended Citation}

Ruffus, A. \& McGinnis, J. (2015). Willful Understanding: Avicenna's Philosophy of Action and Theory of the Will. Archiv für Geschichte der Philosophie, 97(2), pp. 160-195. Retrieved 29 Jun. 2017, from doi:10.1515/ agph-2015-0007 inclusion in Philosophy Faculty Works by an authorized administrator of IRL @ UMSL. For more information, please contact marvinh@umsl.edu. 
Anthony Ruffus and Jon McGinnis

Willful Understanding: Avicenna's

Philosophy of Action and Theory of the Will

DOI 10.1515/agph-2015-0007

Abstract: In this study, we look at two interpretive puzzles associated with the thought of Avicenna that are still of intrinsic philosophical interest today. The first concerns to what extent, if at all, Avicenna's deity can be said to act freely. The second concerns to what extent, if at all, humans within Avicenna's philosophical system can be said to act freely. It is our contention that only through a careful analysis of Avicenna's theory of action can one begin to assess his position concerning the status of the will and so provide a satisfactory response to these two interpretative issues. We hope to show that Avicenna can account for divine freedom and that, at least in the case of prophets and sages, humans too are capable of free action.

\section{Introduction: History and Historiography}

In this study we look at two interpretive puzzles associated with the thought of Avicenna (980-1037), puzzles that are still of intrinsic philosophical interest today. One involves Avicenna's philosophical theology, while the other is central to his psychology and ethics. Both issues, it will be seen, involve Avicenna's conception of the will and what counts as a voluntary and even perhaps free action. It is our contention that only through a careful analysis of Avicenna's theory of action can one begin to assess his position concerning the status of the will and so provide satisfactory responses to the two interpretative issues to which we now turn. ${ }^{1}$

1 A full account of Avicenna's theory of the will would also require discussions of (1) his "political theory", that is, an account of the role of human society in human perfection and (2) the place of the Shari $a$, that is, religious law, and/or natural law in human moral development. Unfortunately, it is beyond the scope of the present article to cover these additional issues, although we hope to treat them in a separate study.

Anthony Ruffus/Jon McGinnis: Department of Philosophy, University of Missouri, 599 Lucas Hall (MC 73), One University Blvd., St. Louis, MO 63121-4400, USA; ruffusa@umsl.edu/ mcginnis@umsl.edu 
The first puzzle, in brief, begins with Avicenna's insistence that divinity is immutable and impassible. As such, reasons Avicenna, the deity cannot come to have some will that it has not had from all eternity, for this would be a type of change. Next, Avicenna argues that whenever there is a complete cause, the concomitant effect of that cause must come to be simultaneous with the cause. ${ }^{2}$ Now the divine will, power and knowledge are the complete cause for the existence of the world, and these are again unchanging. Consequently, Avicenna concludes, because God has existed from all eternity, God must have been causing the existence of, that is, creating, the world from all eternity. Responding to this argument, no less than the great Muslim theologians al-Ghazālì (d. 1111) and Fakhr al-Dīn al-Rāzī (d. 1209) as well as the Christian theologian Thomas Aquinas (d. 1274) raise the first puzzle: Avicenna's argument eliminates divine volition in any meaningful sense and renders the creative act no different than a matter of natural necessity. ${ }^{3}$ In other words, Avicenna's deity appears to be no different than a natural force like gravity and so hardly worthy of worship.

The second interpretative puzzle concerns reconciling Avicenna's apparently strong causal determinism as found in his metaphysics and natural philosophy with his occasional ethical claims that humans are morally responsible for their own actions and in fact can change their moral temperaments. Thus some scholars such as Goichon, Gardet, Hourani, Marmura, Frank, Michot and Belo, focusing on Avicenna's physical and metaphysical writings, see Avicenna as a determinist. ${ }^{4}$ Others such as Ivry, Goodman and Janssens (and, to an extent, Rashed) make Avicenna an advocate of free will (or at least suggest that there is room for free will in his system). ${ }^{5}$ Still others simply label him a compatibilist. ${ }^{6}$ Since on at least certain conceptions of determinism and free will, the two notions are incom-

2 See Avicenna 1957-1960, V. 8; Avicenna 2005, IX.1 [4] and Avicenna 2009, III.11 [2].

3 See al-Ghazālī 2000, Disputation 3; Rāzī, in Avicenna 1957-1960, V. 3, 69-71; Aquinas 1965, III.4. More recently, see Zedler 1948, 105-59; Gilson 1955, 213; Leaman 1999, 44, and Kafrawi 2007, 179-191. See Druart 2006 for an excellent account of al-Ghazālì's formulation of this problem and his own theory of agency. For a view that denies that Avicenna's God creates of natural necessity, see Acar 2005, Chapter 3. A more recent discussion of this issue can be found in Kalin 2010, and although Kalin's focus is primarily on the creation account of Mullā Șadrā, in his section "Volition versus Necessity", he suggests that what he terms the necessitarian and libertarian views have more in common than previously has been appreciated.

4 See Goichon 1937, 162-3; Gardet 1954-5, esp. 828-31; for Hourani, see Avicenna 1966b, 25-48; Marmura 1984, 172-87; Frank 1992, 23-4; Michot 1986, 61-4 and Belo 2007, Chapter 3 and Conclusion.

5 Ivry 1984, 160-71; Goodman 2006, 81; Janssens 2006b and Rashed 2000, 223-57.

6 McGinnis 2010, 225. 
patible, the second puzzle is to see how Avicenna understands these notions and whether he is committed to both and, if so, how he reconciles them.

Both problems have their historical origin in the Greek philosophical world as well as their counterparts during the formative period of Islamic theology. Consequently, getting a general idea of the historical setting and how contemporary scholars have seen Avicenna responding to that background provides a nice introduction to Avicenna's philosophy of action.

The first puzzle, namely that God must create of necessity given his nature, was already of concern at the time of Plotinus (204/5-270), who took up the issue in Ennead, VI.8, a treatise dedicated to free will and the will of the One. ${ }^{7}$ It is not clear whether this section of the Enneads made it into Arabic or if it is only missing from what has survived. ${ }^{8}$ Whatever the case, Avicenna certainly knew most of the elements in it and the general strategy of this treatise, namely, that only by understanding the divine will can one understand lesser wills, like the human will, that are imperfect reflections of the divine will. As for the issue of the divinity's purported lack of freedom, Plotinus's general response is that as God is absolutely simple, there is no nature in God that forces him to create. ${ }^{9}$

This issue of the relation between God's simplicity and divine attributes, like will, knowledge, power and creating, was also at the fore of one of the more heated discussions among Muslim theologians (mutakallimūn), namely, the ontological status of divine attributes (sifāt). ${ }^{10}$ In general, the mutakallimūn agreed that the Qur'an ascribes two different types of attributes to God: the attributes of the essence (șifāt al-dhāt) and the attributes of action (sifät al-fi $l$ ). Attributes of the essence, like being alive, powerful and knowing, are credited to God from all eternity simply owing to what God is. There is a sense, then, that these attributes are necessary attributes of God. Attributes of action, like his creating or being merciful, in contrast, are credited to God on account of his actions. These attributes are in a sense contingent in that God has, as it were, a choice concerning whether to act or not. In other words, although it would be a contradiction to say that God exists but is not alive (an attribute of the essence), there is no corresponding contradiction in saying that God exists but is not creating (an attribute of action) or even that God never creates.

7 For excellent discussions of this text, see Rist 1967, Chapter 6 and Frede 2011, 130-52.

8 Adamson 2002, 157-9. As both Enneads, VI.7 and VI.9, were translated, there is reason to think that if our section was not translated, at least the content would have been known, perhaps through an oral tradition going back to the Kindī circle.

9 Enneads, VI.8.7.

10 An excellent introduction to the issue is found in D. Gimaret's article in Encyclopaedia of Islam, 2nd ed., s.v. 'Șifāt'. 
Where theologians differed concerned the ontological status of the divine attributes. The orthodox Sunnī position, most commonly associated with al-Māturīdī ${ }^{11}$ (853-944) and al-Ash'arîn ${ }^{-12}$ (874-936), was based upon their reading of the Qur'an. These thinkers viewed the attributes as being real subsisting things in the entity or essence (dhät) that is God. Thus, for these theologians, God is living through a life that is in him or God is knowing through a knowledge that is in him. In contrast, certain rationalist theologians, known as the Mu'tazilites, maintained that the divine attributes are best understood as mere descriptors of God, usually having no greater ontological significance than names for or words said of God.

The specific debate arose over the implications of one's understanding of the divine attributes with respect to God's simplicity or unity or uniqueness (tawhìd). Again both groups of theologians agreed that from all eternity God must be described by the attributes of the essence and that these descriptions are caused by their corresponding attributes. Additionally, recall that the Sunnì theologians were committed to the position that there eternally exists in God a knowledge, power and, at the very least, any remaining attributes of the essence and that all of these are real subsisting things. As a result, observed the Mu'tazilites, the Sunnī theologians are committed to the existence of a plurality of eternals; however, continue the Mu'tazilites, the defining characteristic of divinity is being eternal. Consequently, the Sunnī position, so concluded the Mu'tazilites, leads to a plurality of deities, which directly contradicts either the unity or uniqueness of God.

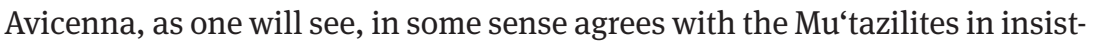
ing on the importance of divine simplicity and unity, and in some sense agrees with certain orthodox theologians in denying that eternity is the defining trait of divinity. Where he fundamentally disagrees with both sides is in the claim that some of the divine attributes hold of God only contingently. For Avicenna, all divine attributes are, in a sense, of the essence and are merely various ways that we, from our limited standpoint, describe the one and absolutely simple attribute of Necessary Existence. ${ }^{13}$ Consequently, both groups of theologians can complain against Avicenna, "Is it not the case that this Necessary Existent must create solely on account of what it is, and so has no freedom not to create?"

The second problem about human freedom likewise occurs within the context of early Islamic theological debates and again concerns the divine attributes. The issue now is how to reconcile God's power (qadar) with his justice ('adl).

11 For a discussion of Mātūîidi’s theology, see Rudolph 1997.

12 For a discussion of Ash'ari’s theology, see Gimaret 1990.

13 Avicenna 2005, VIII.4, esp. 2. 
The notion of qadar is also associated with destiny or fate, and in the Qur'an one often reads of God's destining or determining events, as, for example:

As for the unbelievers - whether you have warned them or not it is the same - they do not believe. God has set a seal on their hearts and on their hearing and over their vision is a veil. There awaits for them a mighty punishment. (2.5-6)

In light of verses like this one and more, al-Ash'arī and many of his followers took divine power to entail divine preordination. Similarly, the jurist Abū Hanifa, the inspiration for the theological system of Māturīdì, is reported to have said: "What reaches you (of evil) could not possibly have missed you, and what misses you could not possibly have reached you.” Despite what might appear as hard determinism, some of these theologians attempted to develop a form of compatibilism, as perhaps seen in the Ash'arite theory of 'acquisition' (kasb), and particularly in the post-Avicennan articulation of that theory by Ash'arites such as al-Ghazālī. ${ }^{14}$ There is also the compatibilism of Māturīdī, who held that while all human actions are created by God and so subject to his will, humans still act by choice (ikhtiyār), and that human's power, given by God, is valid for opposite acts. ${ }^{15}$ Still, as a general rule for orthodox theologians, even compatibilists, the omniscience of God literally means all power is reserved for God and God alone.

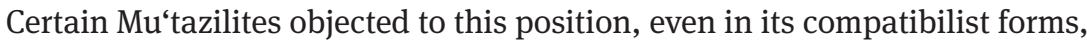
complaining that it would make a mockery of God's justice. ${ }^{16}$ According to these thinkers, God could only justly reward or punish us for our actions on the assumption that we choose to act virtuously or viciously. The Qur'an, however, explicitly claims that God will judge us for our actions and that God is just. Accordingly,

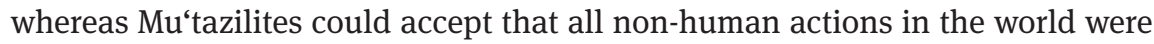
destined or determined, humans must have the power to choose when it comes to right and wrong actions, that is, actions worthy of praise or blame. In other words, according to certain $\mathrm{Mu}^{6}$ tazilites, moral responsibility requires human freedom, where 'freedom' is understood in the libertarian sense of the agent's being able to do otherwise or having the power to choose between alternative actions. ${ }^{17}$

14 See the excellent studies of Marmura 1994 and Druart 2006 as well as a comparison of the Ash'arite theory of acquisition and Stoic compatibilism in López-Farjeat 2007.

15 See Encyclopaedia of Islam, 2nd ed., s.v. 'Māturīdì'.

16 See Wolfson 1976, VIII.ii, esp. 616f. und Hourani 1985, Chapter 6.

17 While it is notoriously difficult to provide primary references for the beliefs of the earliest Mut'azilites, there are still indications that some held a libertarian view of freedom. Thus al-Ash'arī mentions certain Mu'tazilites' view of obedience and disobedience in his Maqālāt al-Islāmìyin (al-Ash'arī 2005, 352), noting that for them obedience and disobedience belong to the same genus (jins) and are like two motions with respect to a single direction, as upward and 
Of course the issue of moral responsibility was also treated among Greek philosophers whose works were translated into Arabic, and so had an influence on Avicenna's understanding. Certainly one of the more important of these is Aristotle's own treatment of the voluntary (Gk. hekousion; Ar. taw') and (deliberate) choice (Gk. prohaeresis; Ar. ikhtiyār) ${ }^{18}$ in Nicomachean Ethics, III.1-5 (and the supplementary discussion in De anima, III.9-12). ${ }^{19}$ Two quick points to note. First, for Aristotle, something is voluntary if (1) it is not done by force, and (2) it is not done through (dia) ignorance; as such, to act voluntarily applies equally to brutes, children and morally responsible adults. Second, the problem of reconciling moral responsibility and some form of determinism would not have been as pressing for Aristotle, as Aristotle's philosophical system may well have been indeterministic or at the very least allowed for non-necessitated (even if perhaps caused) events. ${ }^{20}$

This situation changes with the Stoics. Virtually all ancient philosophers agreed that if determinism and voluntary action, with its accompanying notion of moral responsibility, truly are incompatible, so much the worse for determinism. Thus the problem becomes acute for the Stoics, since for them all things are determined and governed by a universal nature, providence and Fate (heimarmenē) and cannot be but as they are or will be. ${ }^{21}$ Yet, Stoics continued, this cosmic sympathy (sumpatheia) or determinism embraces actions that are "up to us".

downward are with respect to rectilinear motion. The sense of the text is that just as something that can go upward must also be able to go downward, so likewise if someone can be obedient, so must he be able to be disobedient. A near Mu'tazilite contemporary of Avicenna, 'Abd al-Jabbār, also had a robust understanding of freedom, which certainly can be interpreted in libertarian terms (see Hourani 1971, esp. §35). A later source is al-Ghazāli and his analysis of will (irāda) in the Incoherence of the Philosophers, Discussion 1 (al-Ghazālī 2000, 223f.). In that work al-Ghazāil analyzes the will as the power to discern among indiscernibles, that is, to choose from alternative possibilities without any of the possible objects of will necessarily forcing the choice. This final source should perhaps be taken with a grain of salt, as al-Ghazālī is not necessarily presenting his own view, although Țūsī shortly after al-Ghazāli ascribes the view to the "modern mutakallimin" (Avicenna 1957-1960, 105-108). Secondary literature is more forthcoming. See, for example, Hourani 1971, passim, and 1985, Ch. 6; Watt 1973, 232-243, and Wolfson 1976, VIII; there is also useful, but indirect, information in Cook 2003, Ch. 4, where he discusses the efficacy of commanding the good.

18 Interestingly, the Arabic irāda is not the preferred translation for either prohaeresis or boulesis in the Arabic version of the Nicomachean Ethics, even though it is used to translate both terms in non-technical contexts. See Aristotle 2005, Graeco-Arabic Glossary, s.v. 'boulēsis' and 'prohaeresis'.

19 Studies of Aristotle's theory of action include Sorabji 1980, Charles 1984 and Coope 2010, with the most detailed discussion of Aristotle's theory of the voluntary being found in Charles 1984, Ch. 2.

20 See Sorabji 1980, esp. Part I and II.

21 The following is a composite presentation of various Stoic views. As such, not all details are 
Aristotle had introduced the notion of "up to us" (Gk. eph hēmin; Ar. ilaynā $)^{22}$ in his discussion of moral responsibility (Nicomachean Ethics: III.5); however, it is not clear whether Aristotle understands being "up to us" as applying only to morally responsible adults; for in Nicomachean Ethics: V.8, he characterizes the voluntary as what is up to us, which again applies equally to brutes and small children. ${ }^{23}$ In contrast, in the Stoics' analysis of voluntary actions, "up to us" indicates a truly human factor, namely, our 'assent' (sunkatathesis) to the action. Thus, for an action to be voluntary, such that we are morally responsible for it, it must be up to us in the sense that we assent to that action. The Stoics now have the means to show how their causal determinism is compatible with moral responsibility. As one's assent is part of the world order, it too is a constituent of the causal nexus determining one's action. In other words, whereas it is true that things cannot go other than according to the causal order determined by Fate, that determined order is not, as it were, imposed upon us from without heedless of our mental states, attitudes and assent, but includes those causal factors internal to us, and so includes factors that are up to us. Consequently, in that we assent to these actions we are morally responsible for them.

Works by the Stoics were not translated into Arabic, but Alexander of Aphrodisias preserved much of the Stoic position in his De Fato, which was available in Arabic. ${ }^{24}$ Thus, it may have been a source for Avicenna's own conceptions of human moral responsibility and determinism. In the De Fato, Alexander levels a critique against Stoic compatibilism in which he formulates a strong libertarian condition on what counts as freedom (to eleutheron) and moral responsibility. In Nicomachean Ethics, III.2, Aristotle himself had distinguished voluntary actions that might belong to young children and brute animals, from properly human actions that are through (deliberate) choice (prohaeresis). Choice itself is a species of voluntary action, with voluntary action as its genus and resulting from a rational process of deliberation (Gk bouleusis, Ar. rawìya) as its difference. Alexander insists on this distinction and uses it to characterize "up to us". Something is up to us, says Alexander, if in addition to involving assent, it also is

true for each individual philosopher. Still, it does provide the general contours of the Stoics' beliefs. For more detailed discussions of Stoic providence, see Bobzien 1998 and Baltzly 2003.

22 Ilaynā is found in the Arabic translation of the Nicomachean Ethics, but it is not clear that this locution is the only way that the notion was expressed in Arabic. See Avicenna's use of 'an dhātihi and munāsab below.

23 See Coope 2010, $441 \mathrm{f}$.

24 See López-Farjeat 2007 for a discussion of the similarities between Alexander's De Fato and the corresponding discussion in the medieval Islamic world. 
according to reason and selection (kata logon te kai krisin). ${ }^{25} \mathrm{~A}$ truly free human action, then, requires selection and, so, alternatives. Thus, Alexander concludes his philosophical analysis with these words, "[...] we say [being up to us] is owing to our having the power for opposite actions." ${ }^{26}$ For Alexander, like the Mu'tazilites after him, moral responsibility requires having the power rationally to choose between alternatives.

With Alexander's analysis of "up to us”, we come full circle back to Plotinus's discussion of free will in Enneads, VI.8. Like those before him, Plotinus understands a free action as one that not only is voluntary but also is up to us. Again, following Aristotle, Plotinus understands voluntary in terms of (1) an agent's recognizing what it is doing and (2) no physical factors forcing the agent to act. As for what is up to us, for Plotinus, appetites, like hunger, and emotions, like fear, are not up to us, precisely because they are rooted in physiological factors outside of our control; one does not voluntarily become hungry or afraid, for example. For an action then to be up to us, we must have mastery over it, that is, what we desire must come about solely because we willed for it to come to be. For Plotinus, such an act of the will (boulesis) requires that the very desire has its source in our rational part, that is, our intellect. Unlike Alexander, then, who emphasized the sense of selection inherent in Aristotle's notion of prohaeresis, Plotinus emphasizes the rational component. Again, although it is not clear whether Plotinus's Enneads, VI.8 was available in Arabic, Avicenna will virtually reproduce Plotinus's account but with elements of his own.

As for Avicenna's own account of determinism and freedom, it, again, has been the subject of competing interpretations. Before turning to some of those interpretations, however, we should note that for the purposes of this paper, we assume the following working definition of determinism: Some thing $e$ (whether an event or agent) is determined just in case the existence of $e$ is causally necessitated. Here it is important to note that the cause that necessitates $e$ 's existence need not be either different from $e$ (so as not to preclude a self-necessitating entity) or antecedent to $e$. (We return to Avicenna's notion of causal necessity in the sequel.)

Given this definition of determinism, it is fair to say that the most natural or at least most common interpretation of Avicenna's modal metaphysics and theory of emanation is of one that gives rise to a deterministic system in which every event and entity is in some way necessary. Again, it was in this way that Goichon, Gardet, Hourani, Marmura, Frank, Michot and Belo all read Avicenna, and so

25 Alexander 1983, XIV, 183.27-29.

26 Alexander 1983, XXXVIII, 211.27-29. 
labeled him a determinist. This reading may be called the Standard Interpretation of Avicenna's philosophical system. Although we accept the Standard Interpretation, we also feel that it is incomplete, for it frequently leaves unexplained Avicenna's occasional talk of volitional and even free acts by God and humans. More often than not, scholars either simply ignore this issue or acknowledge it but then do not take it up. So, for instance, in Chance and Determinism in Avicenna and Averroes, Belo recognizes that there is "ethical determinism, or the determinism of the human action," but explicitly excludes it from her otherwise excellent study. ${ }^{27}$

A few scholars address the issue but usually by interpreting away the troubling passages. For example, Hourani in his highly informative analysis of Avicenna's treatise Essay on the Secret of Destiny takes up the issue of reconciling Avicenna's determinism with his claim of moral responsibility. For Hourani, Avicenna achieves this reconciliation by reinterpreting reward and punishment. “[W]hat are described as the 'Rewards' and 'Punishments' of the other life are in fact the inevitable effects of the soul's own behaviour in the present life."28 In other words, God can be exculpated for 'rewarding and punishing' us in the hereafter, because there is no causal break between us in the here-and-now and us there-and-then. Whatever we experience, whether here or there, is nothing more than the necessary effects of a causal series that begins with our actions here on Earth.

Unfortunately, Hourani's Avicenna does not appear to have resolved the seeming conflict between God's justice and his destining all actions. The Mu'tazilites can rightly complain that such a position comes down to the following conditional: If we are morally responsible for our actions in the present life, then we are morally responsible for the consequences of those actions in the afterlife. Of course, the Mu'tazilites are simply going to deny the antecedent, namely that, one can be held morally responsible at all for one's actions, given determinism. Hence, the analysis comes to naught. Our hope in this study is to go beyond the Standard Interpretation by exploring what resources Avicenna has for reconciling freedom and moral responsibility with his determinism.

As for those who have challenged the Standard Interpretation, they have done so from one of two directions: either, (1), they offer an alternative (indeterministic) reading of Avicenna's metaphysics or, (2), they appeal to non-metaphysical Avicennan texts, such as works on ethics, religion or politics in which Avicenna appears committed to free will and moral responsibility.

27 Belo 2007, 4-7.

28 Hourani 1966, 40. 
As for offering a reading other than the Standard Interpretation, Avicenna's modal metaphysics has two key components, either one of which has been reinterpreted so as to allow for indeterminism. These components are Avicenna's understanding of necessary existence (wäjib al-wujūd) and of possible existence (mumkin al-wujūd). Ivry has taken up Avicenna's notion of possible existence, whereas Goodman has turned his eyes to necessary existence. Although we cannot offer an exhaustive examination of these two exegetes, a few concerns about their respective approaches should be raised. ${ }^{29}$

Goodman complains that the interpretation that makes Avicenna a determinist rests on an equivocation of the key notion of necessity. ${ }^{30}$ Goodman rightly notes that Avicenna distinguishes between, on the one hand, absolute or intrinsic necessity, namely, the necessity attributable to God, and relational or conditional necessity, on the other hand, that is, the necessity that belongs to an effect given the presence of its cause. Goodman further claims that, as the entities and events of the created order are not absolutely or intrinsically necessary but only necessary relative to their causes, they are contingent. "Such necessities are a matter of logic," writes Goodman, "but that very fact is sufficient to reveal that they obtain only in a context where the proper relations have been stipulated." 31 Goodman apparently likens Avicennan causal necessitation to modern logical necessity as presumably found in, for instance, material implication and such inferences as modus ponens, where the link between two terms need merely be one of stipulation.

Goodman's analysis is unfortunately brief and, taken straightforwardly, appears inconsistent with Avicenna's own account of the relation between demonstrative logic and causal relations as outlined in Kitāb al-Burhān, I.8. In that text, Avicenna insists that the necessity to which (demonstrative) logic corresponds is the inherent causal relations within the world and that premises true by mere stipulation have no place in demonstrative logic precisely because they do not tell us anything about the world. ${ }^{32}$ Thus, Goodman reverses the apparent explanatory order of logic and causation that Avicenna defends in Kitāb al-Burhān. In short, Goodman's interpretation as it stands seems itself to rest on an equivocation, but in Goodman's case on the key notion of relational necessity.

Ivry takes a different tack to show that Avicenna's system permits real contingency. ${ }^{33}$ He focuses on Avicenna's idea of possible existence, and particularly

29 Both are treated extensively in Belo 2007, 225-28.

30 Goodman 2006, 81.

31 Goodman 2006, 81.

32 See McGinnis 2009, especially Section 1: 'Demonstrative Knowledge'.

33 Ivry 1984. 
on possibility's relation to matter, a suggestion that Gardet also hints at in his La pensée religieuse d'Avicenne. ${ }^{34}$ Ivry's presentation is rich and nuanced but his general idea is that Avicenna's determinism is limited to forms and to matter that has received a form. As for matter considered in itself, according to Ivry there is a sense that it is "a real principle of being, the source of change and privation/evil, unknowable in itself and hence unpredictable in its relation to form." ${ }^{35}$ It is precisely because matter is unpredictable that Ivry thinks that, for Avicenna, there are potential existents and future contingent events of which Ivry adds, "The Necessary Existent does not know these in advance, and cannot know them as such."36

For present purposes, two quick concerns should be raised about Ivry's reading. First, Ivry sees matter as playing a much more positive or active role in sub-lunar processes than Avicenna himself countenances. At Physics I.2 Avicenna insists against Aristotle that uninformed matter is wholly inert and neither desires new forms nor sheds off old forms. ${ }^{37}$ Ivry's vision of Avicennan matter, in contrast, seems to embrace this very notion of tending from one form to another.

Second, Avicenna distinguishes between two fundamentally different types of causal orders: physical causation and metaphysical causation. Physical causation involves such physical processes as heating, cooling, drying, moistening, drawing near, withdrawing and other means of preparing (isti' $d \bar{a} d$ ) the matter. At most, physical causation prepares the matter for the effects of metaphysical causation, that is, it predisposes it to receive a perfection or new (species) form. As such, metaphysical causation involves the causal relations of immaterial entities, such as the Necessary Existent, the Intellects and human souls. Thus, even if Ivry has shown that there is unpredictability at the material or physical level, it is too quick to say that there must also be unpredictability at the intellectual or psychological level. This point applies to anyone who argues from purported unpredictability in the physical realm to freedom in the spiritual realm, which Marwan Rashed obliquely suggests in his extremely insightful article "Théodicée et Approximation: Avicenna". ${ }^{38}$ The issue of freedom, then, requires a discussion of agency and psychology not merely of matter and the physical.

34 Gardet 1951, 57-61.

35 Ivry 1984, 167.

36 Ivry 1984, 165.

37 Avicenna 2009, I.2 [21f.]; also see McGinnis 2012.

38 Rashed's purpose is to address the problem of reconciling, within Avicenna's system, divine justice and God's omnipotence, given the presence of evil. In Section II of his article, Rashed takes up a passage from Avicenna's Fì l-kawn wa-l-fasād, dealing with the ancient doctrine of eternal return in which Avicenna states that human choices and volitions are dependent upon the motion of the heavens. Avicenna notes that if there were eternal return, even our choices and volitions would then be wholly determined. The implication of the passage is that humans have 
The second way of challenging the Standard Interpretation takes up this last point, for this approach shifts the discussion from metaphysical and physical texts to ethical texts. Janssens is perhaps the most ardent exponent of this approach. He observes that Avicenna's comments about moral evil, reforming one's habits and moral responsibility all point to the conclusion that for Avicenna "man has some freedom of choice in developing his moral and intellectual capacities." 39 Of course, to show textually that Avicenna is committed to human freedom is not so much an argument against the Standard Interpretation as it is a statement of the problem: How is one to reconcile Avicenna's determinism with his occasional claims concerning volitional freedom? Moreover, simply to claim that Avicenna is a compatibilist is not much of an answer unless one can further show that he, in fact, has the philosophical machinery to make sense of some form of compatibilism.

It is our hope that in addressing the puzzles that first initiated this study, we can better understand Avicenna's own conceptions of divine freedom and his version of compatibilism, which, we contend, while allowing for human freedom in principle, is only truly exercised rarely and then only by prophets, sages and philosophers. Before turning to these topics, however, we must briefly consider Avicenna's taxonomy of action as well as his account of agency, and particularly his conception of final causality.

\section{Avicenna's Theory of Action: An Overview}

Within the Neoplatonizing-Aristotelian tradition of medieval Arabic-Islamic philosophy, the standard term for 'act' is fi' $l .{ }^{40}$ In the Metaphysics of his Shifä', Avicenna says that by fi'l he means simply, "the occurrence of existence" (husūl al-wujūd), which Ṭūsī glosses in his commentary on Avicenna's Pointers and Reminders, as "the occurrence of existence after privation as the result of some cause". ${ }^{41}$ Avicenna in turn uses fi'l (or as often the hendiadys fi'l wa kamāl, 'act and perfection', Gk entelekheia) to define motion (haraka), which is his most basic

freedom of choice, but at the most Avicenna merely hints at this position and Rashed does not pursue the issue in depth.

39 Janssens 2006b, 117.

40 For a discussion of fi'l, see Wisnovsky 2003, Part I, passim. Unfortunately f'il is a broad notion and used to translate no less than three distinct Greek philosophical notions (Gk. energeia, praxis and poiessis). Hence it easily allows for slippage among its various meanings. When necessary to distinguish the precise sense of $f i^{\prime} l$, we include the Greek.

41 Avicenna 2005, IV.2 [5] and Avicenna 1957-1960, V.2, 63. 
term for actions that involve a process. Loosely, one can think of motion as "the non-instantaneous emergence of potency into act $\left(f^{\prime} l{ }^{\prime}\right)$ ". ${ }^{42}$ Actions and motion, in general for ancient and medieval thinkers, are of three basic kinds: natural, volitional and forced. ${ }^{43}$ Avicenna further discriminates non-forced motion on the basis of whether the motion is invariant (e.g., fire always rises unless opposed by an obstacle) or variant (e.g., humans can move in straight lines or along circular paths). Thus Avicenna identifies four non-forced motions: those that result (1) from nature (non-volitional/invariant), (2) from a vegetative soul (non-volitional/ variant), (3) from an animal soul (volitional/variant) and (4) from a celestial soul (volitional/invariant).

Both natural and volitional actions proceed from an internal principle or power, whereas forced action originates from an external agent. In the case of natural motions and actions, the internal principle is the nature, and the actions follow a single and unvarying course. The paradigmatic example of such a motion is that of a stone's falling toward and remaining at rest at the center of the earth. Other examples include water's cooling, fire's rising and the like.

The internal principle in the case of volitional actions is the soul (nafs). ${ }^{44}$ Avicenna provides two different accounts of volition. In Physics I.5, which is quite brief, Avicenna understands volitional actions as those that are "from oneself" ('an dhätiha), which he glosses to mean "not by force". The phrase may well be a variation on Aristotle's eph' heautōi, "what is up to oneself", from the Nicomachean Ethics, otherwise, it is not obvious how Avicenna understands the difference between what is by nature and what is by volition, which he is distinguishing.

In the Metaphysics, he provides a richer account that is highly reminiscent of Plotinian freedom. There Avicenna maintains that volition must (1) proceed from the agent's recognition (ma'rifa) or understanding ('ilm) that the agent is the cause of the action, (2) the agent is not impeded in its action and (3) the agent consents (radiya, yarda, ridan) to the action. ${ }^{45}$ Given the context, it is almost certain that in the Metaphysics passage, Avicenna is laying out the criteria for specifically intellectual volition, and so applicable solely to humans, Intellect (that is, angels) and God, and not a more general conception of volition applicable to all animals. Such a suggestion seems demanded given the presence of

42 Avicenna 1963, Def. 28 [Ф157] and Avicenna 2009, II.1 [6]. For Avicenna’s technical definition of motion, see Avicenna 2009, Book II.1, and, for analyses, see Hasnawi 2001, 219-55, and McGinnis 2006, 189-205.

43 Avicenna 2009, I.5 [1-3].

44 Avicenna 1959, I.5, $39 \mathrm{f}$.

45 Avicenna 2008, I.5 [1]. 
the Stoic notion of "consent" as well as the Plotinian insistence on intellectual activity. (We return to some of these points in the sequel.)

The final class, forced actions, is a catchall. Unlike both natural and volitional motions, which proceed from an internal principle or power, forced motion always involves an external agent. Actions, then, are forced if they are contrary to nature or one's will, as, for example, a stone that is thrown upward or a prisoner's remaining in his locked cell.

Closely aligned with Avicenna's philosophy of action is a theory of causality. Avicenna defines 'principle', which can stand as the general definition of cause, as "anything that already has a completed existence per se (whether from itself or from another) and then from which the existence of another thing occurs and subsists by it." ${ }^{46}$ Like Aristotle, Avicenna in his mature works focuses his discussion on the four causes: matter, form, agent and end. ${ }^{47}$

The most important cause for understanding Avicenna's philosophy of action is the final cause. ${ }^{48}$ For Avicenna, every agent acts only for some end (ghāya), final cause (gharad) or intention (qașd). ${ }^{49}$ In its most abstract sense, "the end is that for the sake of which the existence of something different from [the end] is realized", whereas among natural things subject to processes, it "is the thing for the sake of which the form occurs in the matter."50 The end, according to Avicenna, always corresponds with some good, whether apparent or real. The good might be, for instance, the good of the natural order, which is fulfilled by natural actions such as when a stone falls downward toward its natural place; or the good might be a 'cognitive' or 'psychological' good, like some imagined pleasure that motivates a volitional action. Moreover, Avicenna insists that the end is the cause of the agent's acting, for Avicenna believes that there is no efficient causality without a final cause..$^{51}$ Indeed, the end or final cause is for Avicenna the cause of the causality of the efficient cause.

It is for this reason that Avicenna believes that ends have a certain mode of priority, albeit not temporal priority, with respect to all other causes, namely, ends are prior in 'thingness' (shay' $y a) .{ }^{52}$ What Avicenna means by 'prior in thing-

46 Avicenna 1985, 'Metaphysics', I.12 [518].

47 Avicenna 1985, 'Metaphysics', I.12; Avicenna 2009, I.10, and Avicenna 2005, VI.1.

48 See Wisnovsky 2002, 97-123.

49 See, for instance, Avicenna 2009, I.13f., and Avicenna 2005, VI.5.

50 Avicenna 2005, VI.1 [2], and Avicenna 2009, I.10 [10].

51 Avicenna 1985, 'Metaphysics', I.12 [519f.]; Avicenna 2009, I.11 [1], and Avicenna 2005, VI.5; also see Kafrawi 2007.

52 See Avicenna 1985, 'Metaphysics', I.12, and Avicenna 2005, VI.5 [27-30]. For a discussion of Avicenna's conception of 'thingness', see Wisnovsky 2000, 181-221. 
ness' (certainly with respect to volitional actions) is that the final cause or end is conceptualized (tașawwur) in the mind or soul of an agent and therein recognized as some good. Only then does the agent act for the concrete realization of that end. Inasmuch as an agent must first conceptualize an end, then, the end must be in one sense prior.

Fakhr al-Dīn al-Rāzì, however, later criticizes Avicenna’s conception of final causation. He argues that although such a conception might work for cognizing agents, it does not work for natural agents and actions, such as a stone's tending downward toward the center. ${ }^{53}$ Al-Ṭūsī in turn attempts to defend Avicenna's account, perhaps not entirely successfully, by noting that when the nature essentially requires something, as, for example, being in a certain place, the natural agent is ordered to that thing as potency is to act. This potency, Ṭūsī tells us, can be thought of as a certain prior awareness (shu'ūr) belonging to the nature. ${ }^{54}$

To finish this brief summary of Avicenna's theory of causality, for him all cause inasmuch as they are causes must co-exist and so exist simultaneously with their effects. ${ }^{55}$ In other words, whenever there is a complete causal nexus, that complement of causes necessitates the effect. If a given effect does not occur, then either one of the necessary causes is absent (for example, the matter is not suitably prepared or, in the case of a volitional agent, the will is not present) or something is hindering or preventing the cause(s) from acting. This latter scenario (namely, when something is hindering or preventing the cause(s) from acting) explains, to Avicenna's mind, why some effects seem to occur only for the most part ( fĩ akthar $=\mathrm{Gk}$. hōs epi to polu) rather than always. ${ }^{56}$ The upshot of this last point is that for Avicenna our world is a thoroughly and causally deterministic system, just as the Standard Interpretation has it.

\section{Volition, Intentional Action and Choice: Divine Freedom}

The above provides the broad contours of Avicenna's philosophy of action, but in order to address the interpretative puzzles that initiated this study, we must return to and closely examine Avicenna's understanding of volitional actions. Avicenna's most extensive philosophical treatments of volition occur while dis-

53 Avicenna 1957-1960, IV.7, 18.

54 Avicenna 1957-1960, IV.7, 18.

55 Avicenna 2009, III.11 [2]; Avicenna 2005, VI.2.

56 Avicenna 2009, I.13 [6]. 
cussing the divine creative action, namely, emanation (fayadān). The details of Avicenna's theory of emanation need not worry us. ${ }^{57}$ What is of interest are two interpretive difficulties that Avicenna's discussion raises: one, how to understand Avicenna's distinction between intention and volition, and, two, how to understand Avicenna's conception of divine freedom or volition.

These difficulties arise from Avicenna's steadfast belief that The Necessary Existent - that is, Avicenna's deity - is absolutely simple and thus wholly free from composition or multiplicity. Because the Necessary Existent is absolutely simple, it is equally impossible, reasons Avicenna, that:

the being of the cosmos should result from [the Necessary Existent] in a way that there is some intention ( $q a s+d$ ) - like our intention - for Its generating the universe and for its [i.e., the universe's] existence such that It intends [Its action] for the sake of something other than Itself. $^{58}$

Here, the phrase "for the sake of" is the standard locution indicating a final cause or end. Thus one might think that Avicenna's primary reason for denying that the Necessary Existent acts for the sake of the world is that the good of the world would be a cause making the divine action an effect. Although this observation is certainly true, this is not the reason that Avicenna himself explicitly gives for his denial.

The explicit reason why Avicenna rejects the Necessary Existent's acting intentionally and acting for the good of the created order is that so acting would embroil the deity in multiplicity and so would jeopardize divine simplicity. ${ }^{59}$ Avicenna enumerates the multiplicity thus: (1) there would be something in the Necessary Existent that is the cause of Its intending, namely, Its knowledge that the intention is necessary, desirable or that there is some good in it; (2) there would be the act by which the intention is acquired; and finally (3) there would be that which is acquired by acting for that intention. All of this Avicenna believes is simply absurd, given that the Necessary Existent is absolutely simple.

Concerning that for the sake of which the Necessary Existent creates, throughout his discussion of volition in his Notes ( $\mathrm{Ta}$ 'lìqāt), Avicenna boldly maintains that although the Necessary Existent does indeed act for the sake of an end, that end is not the created order itself. Instead, the Necessary Existent desires only Itself (Its dhät) as the end of its action.

57 See Davidson 1992, 74-83, and Janssens 2006a. For a discussion of al-Fārābī’s theory of emanation, which influenced Avicenna's own, see also Druart 1992.

58 Avicenna 2005; IX.4 [2].

59 Avicenna 2005, IX.4 [1f.]. 
[The Necessary Existent only] desires Itself. Thus, all of these things [in the created order] are willed for the sake of (li-ajli)] [the Necessary Existent] Itself; however, their being willed for It is not for the sake of some end (gharad), but only for the sake of It Itself because they are something requiring [the Necessary Existent] Itself. It, thus, does not will these existing things because of [these things themselves, but for Its own sake and because they are something requiring [the Necessary Existent] Itself. ${ }^{60}$

In this case, the Necessary Existent wills Its own existence as Its proper good. By willing Its own existence, however, there is also a concomitant existence, explains Avicenna, that can be 'traced back' (munāsab) to the Necessary Existent's willing Itself. ${ }^{61}$ This concomitant existence, claims Avicenna, is the existence of the created order. That concomitant created existence, however, is again not the end or purpose of the Necessary Existent's action. It is simply a residual effect, if you will, of the divinity's willing Its own being.

With this brief background in place, one is ready to appreciate the first problem that Avicenna's account of divine action raises: According to Avicenna, the Necessary Existent cannot come to possess some new will that It did not have from all eternity. That is because, again, the emergence of a new will would introduce multiplicity into the godhead, namely, there would be what possesses the new will, the new will itself and the action that issues from that new will. In terms of the medieval Islamic debate over the divine attributes, then for Avicenna, God's will (and indeed all the divine attributes) must be, for all intents and purposes, attributes of the essence. In fact in his treatment of the attributes of action (sifa fã 'ilìya), Avicenna begins with the absolute simplicity of the Necessary Existent, followed by numerous arguments that all of its actions must be eternal. ${ }^{62}$ Against this background, one can understand why the mutakallimūn complain that Avicenna's deity acts only by natural necessity as It seemingly can act only in one way from all eternity and so has no choice but so to act.

The second interpretive difficulty is closely related to the first: whereas divine action is not intentional (bi-l-qașd), Avicenna tells us, neither is it a natural action. His general reason for denying that the divine action is natural is that, as explained above, natural actions are opposed to volitional action. Since Avicenna argues that the divine action has all the hallmark of (intellectual) volitional action, it is not an act of nature. Again the Metaphysic's criteria for volitional motion are: (1) that it proceeds from the agent's recognition (ma'rifa) or understanding (' $\mathrm{ilm}$ ) that it is the cause of the action, (2) that the agent is not impeded

60 Appendix, 3-9.

61 Appendix, 65-8.

62 Avicenna 2005, IX.1. 
in its action and (3) the agent consents to the action. ${ }^{63}$ Therein lies the puzzle: According to Avicenna, emanation is neither a natural action nor an intentional one, and yet despite not being an intentional action it is supposedly a volitional action. To say the least, Avicenna's intention is a bit obscure and leaves one wondering what he means by 'volition'. Certainly, if one said, "I willed to drink the glass of bourbon but I did not intend to do so" the listener would rightly look askance at him.

So the questions before us are (1) how to understand the distinction that Avicenna draws between volitional (bi-l-irāda) and intentional (bi-l-qașd) actions and (2) whether Avicenna's deity is bound by natural necessity or there is some sense that it is a free agent. Let us take up the problem of distinguishing volitional and intentional actions first, which in turn provides some of the material for addressing the second problem.

In the Notes, Avicenna again identifies natural and volitional actions, but now he focuses primarily upon the cognitive component. ${ }^{64}$ He does not mention the "no impediment" condition, but presumably this is taken as a given as the explicit issue is the divine will. ${ }^{65}$ In the Notes, he adds that there are three principles from which volitional actions proceed: "every action that proceeds from a will, the principle of that will is either understanding ('ilm) or opinion (zann) or the (compositive) imagination (takhayyul)" ${ }^{66}$ Indeed the three can be traced back to Plato's famous tripartite division of the soul (Republic, IV, 436b-441c) appetite, sprit and reason - albeit filtered through Aristotle's discussion of the principles of motion for animals (De anima, III.9-11). It is worth noting that in both Aristotle's discussion and Avicenna's in his Metaphysics (and implicitly in his Psychology too), only two motive principles are mentioned: imagination and discursive thought (fikr). ${ }^{67}$ The new identification of three principles of volition is probably rooted in his need to generalize the discussion of volition so as now

63 Avicenna 2005, IX.4 [3].

64 Appendix, 17-25.

65 We are aware that there is another way to understand Avicenna's discussion. The "consensus condition" could simply refer to Aristotle's condition that a volitional action be unforced. If so interpreted, Avicenna's understanding of volition simply would be that of Aristotle from the Nicomachean Ethics, an action is volitional only if it is (1) cognitive and (2) not forced. Although we hold open this interpretation, we also want to explore the real possibility that Avicenna is addressing the larger Greek commentary tradition concerning the theory of volition as well as issues that arise from within his own Islamic intellectual tradition.

66 Appendix, 23-5.

67 See Avicenna 1959, IV.4, where the focus is primarily on imagination but where his examples of a carpenter or doctor's actions implies discursive thought. He explicitly mentions both in Avicenna 2005, VI.5 [7f.]. 
to include divine volition, but can also be derived from Avicenna's own advancements in psychology. To be more explicit on this last point, volitional actions have some pleasure or good as their end (gharad). Because, for Avicenna, there are three sources by which an agent recognizes some good - through the external senses, internal senses ${ }^{68}$ and the intellect - so there must be three principles from which volitional actions can proceed. ${ }^{69}$ The compositive imagination recognizes sensible goods, which satisfy our appetites, opinion recognizes those goods associated with the internal senses and understanding recognizes the goods of the intellect. $^{70}$

As in Plotinus's discussion of "up to us", Avicenna in the Notes sees an inherently passive element in both the case of actions motivated by imagination and opinion.

The whole of [what is according to either opinion or imagination] is owing to some end, and passivity accompanies [the end], since the end affects what possesses the end and so then it is acted on by it. ${ }^{71}$

Here it is worth noting that even if Avicenna did not have a translation of Plotinus's Enneads, VI.8, he would have learned this point from al-Kindī (d. 873), who clearly knew the Plotinian text. ${ }^{72}$ The point that all thinkers insist upon is that the individual is acted upon by the object of imagination or opinion. In these cases, the imagined or opined good associated with the object functions as an end so as to initiate one's motion toward that end. Moreover, by obtaining that good (if it is a real good and not merely an apparent good), the agent is thereby improved. Thus, for example, being of the opinion that there may be some (future) risk, the agent acts in a way to minimize the potential harm and provide for the future. Or, again, the agent may imagine how some apparent good might improve or give pleasure to the agent and thus (imaginatively) seeing in one's mind's eye that future possible state, acts so as to realize that imagined good.

68 Aristotle identifies a number of different operations with imagination (De anima, III.3), and Avicenna carefully distinguishes these various operations into the internal senses. For a discussion of Avicenna's doctrine of internal senses, and particularly the compositive imagination, see Black 2013.

69 See, for instance, Avicenna 2005, IX.7 [4-9].

70 We are grateful to an anonymous referee for helping us with this formulation and pointing out the similarities between Avicenna's discussion and Aristotle's De anima III.9-11 passage.

71 Appendix, 32-4.

72 See al-Kindī 1998, 169-71. That al-Kindī would have known the relevant passage is strongly suggested by the fact that the so-called Theology of Aristotle was translated within the Kindi circle, and the Theology itself is a redaction of books IV-VI of the Enneads. 
Here one should observe that the elements of passivity, which Avicenna enumerates in acting for some imagined or opined end, are virtually the same that he listed in the Metaphysics when explaining why the divinity does not act by intention: (1) The end or intention, which is not yet concretely possessed, but which causally acts upon the agent so as to initiate its action, (2) the action itself, which will be a certain process, namely, the actualization of some potential and (3) the good or benefit, which is achieved from the action.

Avicenna next turns to actions arising from understanding or causal knowledge ('ilm). ' $\mathrm{Ilm}$, within the Arabic philosophical tradition, refers to a deep understanding of reality that grasps the very underlying causes and essential features of things. ${ }^{73}$ As an example of volitional actions proceeding from 'ilm, Avicenna mentions the geometer and physician acting according to knowledge of the principles of their respective sciences, which give rise to actions in which a right and good order is obtained. Unlike imagination or opinion, understanding is not inherently passive; nonetheless it can be passive, particularly in the case of human knowledge or understanding (as opposed to divine understanding or knowledge).

To explain this last point more fully, Avicenna observes that when we humans will something, the object of imagination, opinion or understanding is first conceptualized. ${ }^{74}$ Now for Avicenna, when we conceptualize (tașawwur) something, $x$, the essence of $x$ - its 'thingness' - can be said to exist mentally within our souls or minds, although we do not yet concretely possess $x$. In certain cases, this mental existence engenders a belief $\left(i^{\prime} t i q \bar{a} d\right)$ that $x$ considered in itself is beneficial or a good that will perfect and complete the individual. This belief that $x$ is good or beneficial in turn gives rise to a desire (shawq) in the appetitive faculty to acquire $x$. When the desire is sufficiently strong such that the volitional agent actually seeks the (purported) good there is choice (ikhtiyār). Finally, choice sets the motor faculty arrayed throughout the muscles in motion so that the human moves in such a way as to acquire $x .^{75}$

To repeat quickly, volitional actions arising from understanding are passive if any of the following three conditions are met: (1) understanding informs an agent of some end that the agent does not possess, (2) that end initiates a physical process of actualizing some potential in the agent and (3) through that process the agent seeks some beneficial or good thing for itself. These points are again the three elements that Avicenna identified with intentional actions in the Metaphys-

73 See Avicenna 1966a, I.7 f.; also see McGinnis 2008, 129-52.

74 Appendix, 39-6 and 105-110.

75 More detailed accounts of this psycho-biological chain, albeit in terms of the faculties of compositive imagination and discursive reason (fikr), are given in Avicenna 1959, IV.2, and Avicenna 2005, VI.5 [3-17]. 
ics passage. Call the intellectual volitional principle that realizes these three conditions "passive-type-understanding". Should none of these three conditions be met and yet an agent still act through understanding, then understanding would not involve a passive component and so it would be active. Call this latter kind of understanding “active-type-understanding”.

We are now in a position to explain Avicenna's seemingly problematic distinction between volitional and intentional actions seen earlier in the Metaphysics. Volitional actions in general refer to the genus of actions that are essentially not forced but are cognitive and consensual. One species of volitional actions involves passivity. As such (1) one's power of volition must be acted upon by an end or intention inasmuch as the end or intention has a prior existence in the soul as an object of conceptualization, and as such is a cause of the willing; (2) the action resulting from the volition must itself be a process; and (3) there must be some (real or apparent) good or benefit that one anticipates to achieve at the end of the process, that is to say, the end or good does not already belong to the agent essentially. Call this species of volitional actions "intentional actions". Intentional actions can be further divided into those subspecies that have as a principle of volition (i) imagination, (ii) opinion and (iii) passive-type-understanding.

Additionally, there is that species of volitional actions that is inherently active, that is, it does not involve passivity and so does not involve a process and thus does not require seeking some perfection that the agent lacks. Such actions have active-type-understanding as their principle of volition, and the end of action is not some external good but an internal good, like one's very being (dhāt) as when the Necessary Existent wills Its own being or existence, and there flows from that action the concomitant emanation of our world.

Understanding in what sense the divine action is volitional, namely, that it does not involve a passive element - that is to say, there is no (external) final cause acting upon the deity - goes part of the way in addressing our primary question: In what sense, if any, is divine action free and not merely a matter of natural necessity? For there can be little doubt that Avicenna's Necessary Existent is not impeded in Its action, recognizes that It is acting and consents to that action. Thus the divine action is volitional according to Avicenna's analysis of volitional actions, albeit not intentional, that is, an action that involves some element of passivity.

Moreover, of the various species of volitional actions that Avicenna countenances in his philosophy of action, the sort of action under which divine action falls - namely, one issuing from active understanding - is the best candidate to be a free action. It is here, however, that the Mu'tazilites may object that in fact Avicenna's analysis of volitional action is sufficiently impoverished to preclude any action's being free, for Avicenna does not include choice as an essential com- 
ponent of volitional action. As we saw when discussing the Mu'tazilites' notion of divine justice, choice (ikhtiyār) was for them an essential element in volition. Even the Sunnī orthodox theologian, Māturīdī, had insisted that choice must be a part of volition. Thus for these theologians, if some agent has no choice with respect to an action, then that action must be necessary, and so is not free and so one cannot be held morally responsible for it. The objection moves quickly and, to assess its cogency, we must consider the notion of choice that underwrites it.

The Arabic ikhtiyār comes from the root Kh-Y-R, and, like the English word 'choice', this root carries with it not only the idea of 'to choose', that is, to have options, but also of 'being choice worthy', in other words, to be good or excellent, as in a choice steak or choice piece of real estate. ${ }^{76}$ In general, Avicenna seems to use ikhtiyār most frequently in the latter sense of being directed toward a good, although he occasionally uses it in the sense of preferring among options. ${ }^{77}$ So, for instance, although Avicenna never appears formally to define choice, as, for example, al-Fārābī does, ${ }^{78}$ both senses of choice appear at play in his definition of the practical intellect ('aql 'amalī) in his Book of Definitions: "The practical intellect is a faculty of the soul that is a principle for the appetitive faculty to produce motion toward what is chosen from among the particulars for the sake of some opinioned or understood end". ${ }^{79}$ Here one sees the sense of choosing since something is good because, as seen earlier, ends are real or apparent goods. Additionally, the sense of choosing from among options is seen in Avicenna's ikhtiyār min ("to choose from among") construction. (Admittedly this construction may well have been "loose talk" on Avicenna's part, for, as we saw, the notion of options played no explicit role in Avicenna's analysis of volition. ${ }^{80}$ Call these different nuances of choice "choice" (with respect to options) and "choice ${ }_{\text {" }}$ " (with respect to the good).

As for choice , namely, a choice made on the basis of some anticipated good, Avicenna notes that it is intimately linked to seeking (țalab) some imagined,

76 See Lane, Arabic-English Lexicon, s.v. kh-y-r. The root sense is to become possessed of some good (khayr), from which is derived the idea of choosing what is good.

77 See Goichon 1938, s.v. 'ikhtiyār'.

78 Al-Fārābī 1985, 204, 9-11: “The tendency to what one perceives, in general, is volition. So, if that [tendency] results from sensation and imagination it goes by the name 'volition', whereas if that results from deliberation and reason, it is called 'choice'. The latter is proper to humans." 79 Avicenna 1963, पा 22.

80 Interestingly, choice as including options does appear in Aristotle's definition of prohaeresis (=ikhtiyār) in the Arabic translation of the Nicomachean Ethics. "[Choice] seems to be a voluntary action, except that not all that is voluntary is chosen. Instead, what is chosen is that which deliberation necessitates ( $m \bar{a}$ awjabat al-rawĩya), because choice is only through discrimination and the intellect. It appears that the term 'choice' in our language indicates that which gives preference to one thing over another” (Aristotle 2005, III.2 [16f.]). 
opined or intellectual good. ${ }^{81}$ The Arabic talab, which is central to choice ${ }_{g}$, conveys the sense not only of seeking but also of wanting or requiring. In general, then, the idea is that choice involves some lack or absence of a proper good that is, something that the agent is in want of - that the object sought fulfills. It is important to note that choice, again in the sense of choice worthy, arises only insofar as the agent possesses what Avicenna is calling a passive element, which corresponds with a certain potential to be set in motion.

This analysis provides an immediate reason why Avicenna would exclude choice ${ }_{\mathrm{g}}$ from his account of volitional action. Since choice ${ }_{\mathrm{g}}$ involves an inherent passive element, if it were essential to volitional actions, the active-type-volitional actions, which Avicenna's analysis suggested, would be impossible; for their defining trait is that they do not involve a passive element. The very fact that active-type-volitional actions at least appear to be among the logical possibilities that a theory of action would want to consider gives one a reason to omit choice from the list of necessary desiderata for a general theory of volition or at least seriously to qualify what is meant by 'choice'.

Whereas the above is sufficient to understand Avicenna's hesitancy to include choice as a necessary part of volitional actions, there is another possible reason as well, which has its roots in Plotinus. This second reason exploits the idea seen above, that choice is believed to require options or alternatives. If volitional actions require choice, then, for an agent to choose, the agent must be aware of the various options before it, and these options represent various goods conceived in the intellect of the choosing agent. From a monotheistic point of view, however, this analysis raises by now a familiar theological difficulty. If the divinity must recognize two distinct goods from which to choose, the divine mind must be a composite of at least two concepts corresponding with the two goods, and so would not be absolutely simple. Consequently, Avicenna may have excluded choice from his preferred list of essential elements for a volitional action because he wanted to ensure that divine action is volitional, while also safeguarding divine simplicity (tawhìd).

Concerns such as these clearly motivated Neoplatonic discussions of will and the One. For Neoplatonists, what emanates from the One does so as a matter of necessity precisely because the emanation flows from the One because the One is necessarily and essentially good..$^{22}$ For the One not to emanate and so not to create would be for it not to be Good and so for it simply not to be. Avicenna, likely

81 Avicenna 2005, IX.2 [12].

82 While this might not be the position of Plotinus in Enneads VI.8 (see Frede 2012, Ch. 8, esp. 145-52), it does seem to be the position of Proclus (see Proclus 2001, Argument I). 
knew Plotinus's position on this point. Hence these Plotinian concerns may well be at play in Avicenna's omission of choice in his account of volitional actions. Call this reading of Avicenna the 'Plotinian Interpretation' ${ }^{83}$ Of course, the Plotinian Interpretation seems to land Avicenna in the original puzzle: "Does not God create as a matter of natural necessity given what it is?"

This 'Plotinian Interpretation' is not the only way to read Avicenna on this point. Nașīr al-Dīn Ṭūsī, in his commentary on Avicenna's Pointers and Reminders, rejects the claim that Avicenna's Necessary Existent creates of necessity. ${ }^{84}$ In contrast, Tūisi endorses the position that the deity in fact creates by choice (ikhti$y \overline{a r}$ ). The context of Țūsì's claim is in response to Fakhr al-Dīn al-Rāzì's charge that "the philosophers were in agreement that the eternal cannot be the act of a choosing agent ( $f \bar{a}$ 'il mukhtār)", and so the divine action must be necessary. ${ }^{85}$

Ṭūsì's response moves in two stages: (1) clarify what the philosophers truly maintain and (2) show that in principle the philosophers' position is no different from that of the theologians. To the first point, what the philosophers in fact affirm, Ṭūsī tells us, is that an eternal agent complete in its agency cannot but produce an eternal effect. ${ }^{86}$ Such a claim, however, means that the Necessary Existent cannot produce a temporal effect, such as a cosmos that began, for instance, 10,000 years ago. So it is true that, for the philosophers, an eternal cause complete in its agency cannot choose to create a temporal effect. It is, however, false that such an agent cannot choose absolutely, insists Țūsī, for there is still open to it the option of choosing either to create (eternally) or not to create (at all).

Second, continues Ṭūsì, this situation in principle is no different from that of the mutakallimūn, for they first establish that the cosmos must necessarily be something temporally created. Moreover, in their proof for the temporal creation of the cosmos, they never say a word about the cosmos' agent, let alone that its agent chooses. Consequently, concludes Țūsī, the theologians equally deny that God chooses, for according to their position, God cannot create an eternally existing world but only chooses when to create a temporally generated world. Avicenna and the theologians' positions are in principle the same. In short, Țūsî̀s criticism of Rāzī, comes down to the old adage: What is good for the (theological) goose is good for the (philosophical) gander. Call this reading the 'Nașirean Interpretation' of Avicenna.

This Nașirean Interpretation actually has a textual basis in Avicenna's own discussion of liberality (jūd) from the Metaphysics of the Cure. In the relevant

83 This is the conclusion of Kafrawi 2007, esp. 187.

84 Avicenna 1957-1960, V.3.

85 Cited in Avicenna 1957-1960, V.3, 69.

86 Avicenna 1957-1960, V.3, 70. 
passage, Avicenna treats an agent that is absolutely perfect with no deficiency who provides some good to another, neither desiring, needing nor expecting any good from that other in return. Clearly the agent in question is the Necessary Existent, and Avicenna has this to say of It:

The procession of that thing [i.e., good] from it [i.e., the Necessary Existent] to the other is such that its being from it or not being from it are on par. [This is] to the point that even if that good, which is good relative to the other, were not to proceed from it, [that agent's] states would be the same in every respect as if that [good] had proceeded from it [...] and to the point that even if [that agent] did not bring that [good] into actuality (lam yuf'al), it would not quit being the most worthy and the best. ${ }^{87}$

While the language of choice does not appear in Avicenna's discussion, the two options of choice that Tūūi identified clearly do. In this text, Avicenna, it would seem, is modifying the original Neoplatonic position.

Again the Plotinian Interpretation is predicated on the assumption that not creating would somehow lessen the goodness of the deity or, stated in another way, the goodness of God plus the goodness of creation is a greater or a more complete good than merely the goodness of God alone. Fleshing out Avicenna and Țūsì's point, the goodness of God is infinite, whereas the goodness of creation is only a finite good. To add or subtract a finite to or from the infinite, however, in no way enhances or diminishes the infinite. It is still infinite. In like manner, whether the Necessary Existence creates or does not create, so acting (or not acting) in no way increases nor lessens the divine goodness. It is still infinitely good.

Moreover, divine simplicity is safeguarded, for creating or not creating do not correspond to two distinct concepts in the divine mind. Not creating simply is the negation or absence of the idea of creating. In other words, the options for the divinity are not between distinct types of action, which would require distinct concepts, as, for example, choosing between either reading a book or going to a movie. Instead the only thing that Necessary Existing knows, and to which It consents in either the case of creating or not creating, is the essential goodness that is the very divine being itself.

In general, [the Necessary Existent] does not know the concomitants of Itself - I mean the objects of understanding - and then thereafter consents to them; rather, since their procession is from what [the Necessary Existent] Itself requires [namely, Its own goodness], their very procession from It is itself Its consenting to them. ${ }^{88}$

87 Avicenna 2005, VI.5 [44]. We are grateful to an anonymous reviewer for drawing our attention to the significance of this passage for the Nașirean Interpretation.

88 Appendix, 61-4. 
The object of the divine intellect is the divinity itself. Whether the cosmos exists or not, that object does not change. Thus explicitly for Tūisī and implicitly for Avicenna, the Necessary Existent chooses in the sense that It has the option of whether to create or not to create, and yet whether it creates or not in no way diminishes its goodness or jeopardizes its simplicity.

\section{Causal Determinism and Moral Responsibility: the Human Will}

We now turn to the second of the interpretive puzzles that initiated this study, namely, how is one to reconcile the seemingly strong causal determinism of Avicenna's physics and metaphysics with his claims that humans are morally responsible for their actions. If humans do have free will for Avicenna, then it would have to proceed from an active-type understanding. Unfortunately, it is not immediately clear whether Avicenna thought that volitional action of the inherently active kind could be ascribed to humans. If so, it would almost certainly be rare; it would be a self-referential or self-identifying, even perhaps a self-forming, act for the individual.

In contrast, there is no doubt that Avicenna viewed the vast majority of, if not all, human volitional actions as intentional. Intentional actions are, again, inherently passive. As such they are fully determined by a combination of external causes and internal corporal psychological faculties or powers. Admittedly, Avicenna concedes, it is difficult, in the case of volitional actions, to identify all of the causal constituents, "for volition is incited to act [only] after a number of factors are fulfilled, the enumeration of which is not easy." ${ }^{89}$ Still, he is clear that the overwhelming majority of, if not all of, our volitional acts are causally determined in some sense. For, as Avicenna writes:

The volitions that belong to us come to be after not having been, and whatever comes to be after not having been has a cause. Thus our volition has a cause and the cause of that volition will not be an infinite series of volitions, but things that happen externally, whether earthly or heavenly, with the earthly terminating in the heavenly. ${ }^{90}$

89 Avicenna 2009, I.14 [5].

90 Avicenna 2005, X.1, [12]. 
Thus, it would certainly seem from this passage and others that our actions are fully determined by finite series of physical causes, whether those causes are of a terrestrial or celestial nature.

Avicenna's strong affirmation that intentional actions are causally determined, however, must be assessed against his views on moral responsibility and freedom found in his occasional, indeed somewhat rare, discussions of ethics. ${ }^{91}$ Unfortunately, in the work where he should seemingly treat these issues, The Essay on the Secret of Destiny, he unhelpfully states that whereas God wholly determines our actions, we are in some sense still responsible for those actions. ${ }^{92}$ He is more forthcoming in his short treatise, On the Science of Ethics ( $\mathrm{F} \overline{\mathrm{i}}$ ' $\mathrm{ilm}$ al-akhlāq). For our topic, what is important in that work is his discussion of how humans acquire virtues (as well as vices). Like Aristotle, Avicenna too thinks that virtues and vices are acquired through habituation (i`tiyād), namely, by performing a certain class of actions repeatedly over a long period of time. As for acquiring these moral habits, Avicenna thinks that humans are capable of initiating new processes of habituation. "Whenever some human does not actually have a certain moral character, he can attain it for himself”, Avicenna writes, "and likewise whenever he happens to find himself actually having some moral character, he can, through an act of his volition (bi-irädatihi), turn toward the contrary of that moral character."93 Moreover, Avicenna states that the object of volition (murād) when it aims at the mean, and so at virtue, is freedom (barā'a; probably $=\mathrm{Gk}$. to eleutheron) and mastery (isti'lā'; probably = Gk. to kyrios), particularly freedom from and mastery over the conditions of one's natural temperament. ${ }^{94}$ The language certainly harkens back to both Alexander's and Plotinus's own language on the subject as well as strongly suggests that Avicenna thought that we are morally responsible for our own habituation and actions, and so perhaps in some sense that we are free. The issue, then, is whether he can consistently hold this position given his strong notion of causal determinism.

Concerning whether Avicenna can give a consistent account of moral responsibility, we start with something of a bold conjecture. Given many of the deep structural similarities between Plotinus's own treatment of volition and the One from Enneads, VI.8, and Avicenna's own account of volition in the Notes, we

91 See, for example, Avicenna 2005, IX.7-X.5, Avicenna 1957-1960, VIII-X, and Avicenna 1986. 92 See Avicenna 1966b. That work lists three premises necessary for understanding the determination (qadar) of our actions, (1) that God causally determines everything in our world, (2) that we should understand reward and punishment in the afterlife and finally (3) that there is indeed an afterlife with rewards and punishment seemingly determined by our actions here and now.

93 Avicenna 1986, 120.

94 Avicenna 1986, 123. 
tentatively suggest that Avicenna views the account of volition developed in the Notes as equally applicable to humans, albeit in an inferior way, just as Plotinus had done before him.

Recall then that in the Notes, Avicenna introduced a notion of "traced back" (munāsab) to show that, even though the Necessary Existent gained no benefit from creation, It was still responsible for creation because creation is traced back to It and It recognizes and consents to the world's creation. ${ }^{95}$ Although it would be impossible to say with certainty, it is reasonable to think that Avicenna's notion of "traced back" is his attempt to capture the ancient notion of "up to oneself". If, then, Avicenna is following Plotinus, Avicenna could apply this same schema to the case of human moral responsibility. Consequently, by Avicenna's analysis, one would be morally responsible for some action, even though that action is completely causally determined, just in case: (1) the action is traced back to the individual as its agent - that is, the action results from principles inherent in the agent of which at least one of those principles will be imagination, opinion or understanding (whether it be of the passive-type-understanding or active-type-understanding variety) and nothing external hinders the agent from so acting - (2) the individual recognizes that he or she is the agent of the act and (3) the individual consents to the action. This in effect is the interpretation of moral responsibility that Hourani, in his analysis of The Essay on the Secret of Destiny, ascribes to Avicenna. As we noted, if this is all Avicenna has to say on the subject, then it would have been greeted with only limited success within its historical context, given the debates between Alexander and the Stoics as well as among the mutakallimūn.

Thus taking seriously the Greek and Islamic debates surrounding freedom and choice, the question we raise is: might Avicenna have countenanced anything analogous to the Nașirean Interpretation of divine freedom for humans, albeit, significantly inferior to that of divine freedom? Such a position would have to allow for humans in principle to have an option to choose whether to will or not to will in some, perhaps extremely limited, cases, and yet be compatible with Avicenna's deterministic system.

If Avicenna does have such a conception of human free will, then the paradigm case of such freedom would be the divine creative act. The divine creative action, recall, involves the divinity's willing Itself (dhât) as Its own proper good, which has as its principle the Necessary Existent's own active-type-understanding of Itself as its end, with creation resulting not as some good desired by the

95 Appendix, 65-8. 
Necessary Existent but as a concomitant that can be traced back to the deity's willing Itself.

Analogously, human freedom would involve the soul's willing its own essential good as a result of active-type-understanding. Now according to Avicenna's psychology, there is a real sense that the human is essentially an immaterial substance. Hence, there is an equally real sense that the human is essentially his or her intellect, for to be immaterial is to be an intellect. ${ }^{96}$ Additionally, the proper perfection and end of an intellect is, for Avicenna, understanding ('ilm), what he also calls intellectual perception. For Avicenna, all forms of perception involve some proper pleasure, and thus intellectual perception also has an associated intellectual pleasure, and so is some good. ${ }^{97}$ Unfortunately, bemoans Avicenna, this pleasure is best experienced only in a disembodied state. Still, he asserts, some humans do get a faint taste of this intellectual pleasure in the here and now. Some of these, namely, prophets, sages and true philosophers, pursue understanding and so perfect their very selves as intellects, whereas others who have had a glimpse of their true selves forget (yansá) what they are, namely that they are an immaterial substance, and because of their forgetfulness pursue the pleasures of the body. ${ }^{98}$ Avicenna reserves the deepest rings of hell for those who have had this recognition of their true selves and the concomitant intellectual good and pleasures and yet forget what their true selves are. Thus a few words seem warranted about this Platonic notion of forgetting our true selves.

We begin with a question: Why does one forget something? The simplest answer is that one stops attending to or being aware of that thing because something else has come up that preoccupies the mind. Avicenna agrees. Humans can become so preoccupied with the body and the goods associated with it that they cease being aware of what they really are, namely, an immaterial intellect, and of their intellectual good. In this case, they no longer include the good of their true selves in their deliberations and so that good plays no role in the causal series that makes up their lives. Instead, they will and act based upon those passive volitional principles over which they have no control and mastery. It is, then, in Avicenna's notion of attending or being aware of one's true self (shu'ūr bi-dhāt) that we catch a glimmer of choice ${ }_{0}$ in Avicenna's account of human volition. ${ }^{99}$ As long as one chooses to be actively aware of one's true self and its good, and

96 Avicenna 1959, V.2. This point is the goal of Avicenna's discussion of the 'true account of the soul' and his famous 'floating man' argument; see, for instance, Avicenna 1959, V.7, 252-7.

97 Avicenna 2005, IX.7 [4-15].

98 Avicenna 2005, IX.7 [16].

99 For discussions of Avicenna on self-awareness, see Black 2008, 63-87 and 2007, especially Chapters 4 and 5. 
so does not forget oneself, there is true human freedom. In contrast, when one forgets oneself, and so chooses not to be actively aware of what one truly is, one ceases to have mastery and control over the causal nexus that makes up one's life.

Two further subsidiary points should be made about Avicenna's vision of human self-awareness and the process that it initiates. First, for Avicenna, there is an element of the divine in active self-awareness. Thus Avicenna writes in his Psychology, when "the soul conceptualizes itself [...] [it] makes itself an intellect, something that intellects and something that is intellected." ${ }^{100}$ In other words, in active self-awareness the human intellect becomes thought thinking itself, the very description Avicenna uses for the divine. Second, this self-awareness can initiate, as a concomitant action, a process of scientific inquiry, namely, an exploration into the causal structure of the world. In one place, Avicenna describes this inquiry into the Cause of the world as, in its purest sense, the contemplation of God and thus becoming like God (ta'alluh). ${ }^{101}$ While this process of inquiry is not the proper end of one's self-awareness (becoming like God is), this process can be traced back to the agent's willing his or her own proper perfection qua intellectual substance.

The foregoing is certainly speculative (and more must be said), but if correct, then Avicenna may well have the wherewithal to provide an account of human freedom analogous although inferior to the notion of divine freedom suggested by Tiūsī, albeit, a freedom exercized only by the rare few - perhaps only prophets and sages. For in the action noted, there is a self-realization (or at least the initiation of a process of self-realization) that has as its principle active-type-understanding and from which certain concomitant actions result. As such, it mirrors (admittedly imperfectly) the divine creative act.

To conclude, there may not be anything surprising in a medieval thinker's setting up divine contemplation as the proper perfection of humans, or even that only in contemplating the divine are one's actions free. What is perhaps surprising, is that Avicenna had a fairly well-developed theory of action, and how well he integrated his conclusions into that theory. What we hopefully have done here is to take a first exploratory look at Avicenna's philosophy of action, and shown how it begins to provide answers to two long-standing interpretive puzzles in Avicennan scholarship.

100 Avicenna 1959, V.6 [239].

101 Avicenna 2005, X.4 [7]. 


\section{Appendix: "Explaining Will (irāda)" - from Avicenna's Ta'līqāt ${ }^{102}$}

[11] All existing things proceed from [the Necessary Existent] Itself (dhātihì), namely, they are something requiring [the Necessary Existent] Itself. So they are not something It seeks, because It [only] desires Itself. Thus, all of these things are willed for the sake of (li-ajli)] [the Necessary Existent] Itself; however, their being willed for It is not for the sake of some end

5 (gharad), but only for the sake of It Itself because they are something requiring [the Necessary Existent] Itself. It, thus, does not will these existing things because of them themselves, but for Its own sake and because they are something requiring [the Necessary Existent] Itself. An example would be if you desired something, and so all that proceeds from it would be an object of desire for you for the sake of that very thing. We will something only for

10 the sake of some appetite or pleasure, not for the sake of the very thing desired. Now were appetite, pleasure or the like among the things that are self aware [12] (volition belonging only to something that is self aware) and [if] the procession of the acts were from [the acts] themselves, [the acts] would will those things for their own sake because they proceed from themselves.

15 Next, whatever proceeds from the agent is either essential or accidental. What is essential is either natural or volitional. Now any action that proceeds from understanding (' $\mathrm{ilm})^{103}$ is neither by nature nor natural, and so consequently [every action that proceeds from understanding] is volitional. Now every action that proceeds from an agent - where the agent recognizes (ma'rifa) the procession of [the action] from him and recognizes that he is its

20 agent - that action proceeds from his understanding. Also, every action that proceeds from a will, the principle of that will is either understanding ('ilm) or opinion (zann) or the (compositive) imagination (takhayyul). An example of what proceeds from understanding is the action of the geometer or physician. An example of what proceeds from opinion is being cautious of that in which there is risk, while an example of what proceeds from imagination

25 is seeking something that appears to be either noble or excellent in order that a likeness to the noble or excellent thing is obtained. It is simply not the case that the action of the Necessary Existent should be according to either opinion or imagination. [That is] because the whole of that [namely, what is according to either opinion or imagination] is owing to some end, and passivity accompanies [the end], as the end affects what possesses [13] the

30 end and so then it is acted on by it. The Necessary Existent through Itself, however, is necessary in all respects. So if a given end comes to be from It, then there is no respect that the Necessary Existent through Itself is acted upon by the end. Therefore, Its willing must be of the understanding variety.

Here we really need to distinguish the idea of will. When we ourselves will something, we

35 conceptualize that thing in the manner of opinion or imagination or understanding, where

102 We took as our base text Seyyed Hossein Mousavian's edition of al-Ta‘līqāt (Avicenna 2013), $11-17$.

$103 \mathrm{Ilm}$ is the cognitive term for knowing something completely because one knows the causes of the thing. 
that conceptualized thing is in fact agreeable in the sense that it is excellent or beneficial. There then follows upon this conceptualization and belief a desire for it and a desire to acquire it. So when the desire and resolve are strong, the power that is in the muscles moves the body to acquire it, and for this reason, our actions follow because of the end.

Now we have already explained that the Necessary Existent is complete - indeed above 40 completion - so it is simply not the case that Its action should be for the sake of some end. Hence, neither is it the case that It should understand that something would be agreeable for It so that It would yearn for it and then thereafter acquire it. Its will, with respect to understanding, then, is that It understands that that thing in itself is good and excellent, [14] and the existence of that [thing the Necessary Existent understands] must in some way 45 be such that it is a superior existence where that thing's coming to be $(\mathrm{kawn})^{104}$ is better than its not coming to be. ${ }^{105}$ So for the thing to exist, there is no other will needed beyond this [divine] understanding. In fact, [the Necessary Existent's] very understanding of the order of possible things according to the superior arrangement is a cause necessitating the existence of those things according to the existing order and superior arrangement.

In general, [the Necessary Existent] does not know the concomitants of Itself - I mean the objects of understanding - and then thereafter consents to them; rather, as their procession is from what [the Necessary Existent] Itself requires, their very procession from It is itself Its consenting to them. Consequently, their procession from It is not something beneficial for Its own sake, but is something traced back (munāsab) to the agent itself. Whatever is not 55 beneficial and yet the agent understands that he is its agent is something [the agent] wills because it is traced back to him.

Hence we say that these objects of understanding proceed from something requiring the very being of the Necessary Existent through Itself (dhāt wājib al-wujūd bi-dhātihi) - [It Itself] being what is desired by It - together with an understanding of It that It is their agent 60 and cause. Whatever proceeds from something according to this description is not something beneficial to that agent. Every action that proceeds from an agent and is not useful to him is something he willed. Consequently, all things are willed owing to the Necessary Existent, [15] and this willed thing is not the end because the end with respect to Its consenting to the procession of those things from It is that It requires Itself as what It desires. 65 So Its consenting to those things is for the sake of Itself, which is the final cause (ghāya) of the action itself of [the Necessary Existent]. An example of this is when you love something for the sake of some person, the object of love in fact is that person, and so therefore the absolute object of desire is [the person] himself. An example of will in us is that we will something and long for it because we need it, while the Necessary Existent wills it in the 70 aforementioned way and yet does not yearn for it because It has no need for it.

So there is no end except together with a desire, for it is said, "Why did he seek this?" and then it said, "Because of his yearning". Where there is no desire, there is no end. In that case, then, there is no end in acquiring what is conceptualized. There is no end in what follows upon the acquisition of it, as the acquisition of the thing is an end, and whatever 75 benefit that follows upon that acquisition is also an end. [16] Sometimes the final cause is the action itself, whereas sometimes it is the benefit that follows upon the action. An

104 Or "the being of that thing". 105 Or "its not being". 
example is going for a walk, which might [itself] be a final cause, but getting exercise might [also] be a final cause, and likewise, building might be an end as well as shelter.

80 Were it that a person recognized the perfection that is the true nature of the Necessary Existent and thereafter organized the states of affairs that are after It according to Its model (mithāl) such that the state of affairs is according to the utmost degree of organization, then the end would in fact be the Necessary Existent Itself, which is the perfection. So if the Necessary Existent Itself is the agent, then It is also the final cause and end. Likewise, if

85 we recognized, for instance, the perfection in some building that we are going to build and thereafter arranged the states of affairs of that building according to the requirements of that perfection, then that perfection is the end. When that perfection is the agent, the agent and end are one. An example of this will in us is when we conceptualize something and recognize that it is beneficial or proper, and then this belief and conceptualization moves

90 the appetitive power. Unless there is a preponderance and as long there is no obstacle, then between the aforementioned conceptualization and belief and between the motion of appetitive power there is no other will except this belief itself.

The will of the Necessary Existent is similar. [17] Indeed the intelligibility of things for It is according to the way that we indicated, namely, it is the cause of the existence of things,

95 since it does not need to desire what It intellects and seek to acquire it. We ourselves need only the appetitive power and the will to desire in order that through (bodily) instruments (ālat) we seek what is agreeable to us; for the action of the (bodily) instruments follow upon a desire that precedes [that action]. In the case where there is no need for this desire and the use of (bodily) instruments, there is only understanding pure and simple of the organiza-

100 tion of the existents. It understands the most superior ways according to which the existents must be, and It understands the excellence of the arrangements.

This is the final cause itself, for if we were to arrange something as an existent, we would first intellect the superior order and thereafter arrange the existents that we will into existence according to that superior order and what it requires. So when the order and the per-

105 fection are itself the agent and thereafter the procession of existing things is from what [the agent] requires, then providence is really occurring there, namely, it is the will itself, where the will itself is the understanding. The reason for that is that the agent and final cause is one thing.

Acar, R. 2005. Talking about God and Talking about Creation: Avicenna's and Thomas Aquinas' Positions. Leiden.

Adamson, P. 2002. The Arabic Plotinus: A Philosophical Study of the "Theology of Aristotle." London.

Alexander (of Aphrodisias). 1983. Alexander of Aphrodisias on Fate. Ed./trans. R. W. Sharples. London.

Aquinas 1965. Quaestiones disputatae de potentia. Ed. P. M. Pession. Turin.

Aristotle 2005. The Arabic Version of the Nicomachean Ethics. Eds. A. Akasoy/A. Fidora. Trans. D. M. Dunlop. Leiden.

Al-Ash'arī 2005. Maqālāt al-Islāmīyīn. Ed. H. Ritter. Berlin.

Avicenna 1957-1960. Pointers and Reminders with Commentary of Nașīr al-Dīn Ṭūsī.

Ed. S. Dunyá. Cairo.

-. 1959. Avicenna's De anima. Ed. F. Rahman. London.

-. 1963. Book of Definitions. Ed./trans. A.-M. Goichon. Cairo. 
-. 1966a. Kitāb al-burhān. Ed. 'A. R. Badawī. Cairo.

-. 1966b. "Essay on the Secret of Destiny". Bulletin of the School of Oriental and African Studies 29, 25-48. Ed./trans. G. Hourani.

-. 1969a. al-Af‘āl wa-l-infi‘ālät. Ed. M. Qāsim. Cairo.

-. 1969b. al-Kawn wa-l-fasād. Ed. M. Qāsim. Cairo.

-. 1985. al-Najāt. Ed. M. T. Dānishpazhūh. Tehran.

-. 1986. "Fì ‘ilm al-akhlāq”. In Tis“ rasā’il fī l-ḥikma wa-l-ṭabīyāt. Ed. H. ‘Āṣī. Beirut.

-. 2005. The Metaphysics of The Healing. Ed./ trans. M. E. Marmura. Provo.

-. 2009. The Physics of The Healing. Ed./trans J. McGinnis. Provo.

-. 2013. Kitāb al-Ta 'līqät. Ed. S. H. Mousavian. Tehran.

Baltzly, D. 2003. “Stoic Pantheism”. Sophia 42, 3-33.

Belo, C. 2007. Chance and Determinism in Avicenna and Averroes. Leiden.

Bertolacci, A. 2006. The Reception of Aristotle's Metaphysics in Avicenna's Kitāb al-Šifā'. Leiden.

Black, D. L. 2008. “Avicenna on Self-Awareness and Knowing that One Knows”. In The Unity of Science in the Arabic Tradition: Science, Logic, Epistemology and their Interactions. Eds. S. Rahman/T. Street/H. Tahiri. Dordrecht, 63-87.

-. 2013. "Rational Imagination: Avicenna on the Cogitative Cower". In Philosophical Psychology in Medieval Arabic and Latin Aristotelianism. Eds. J. Tellkamp/L. X. LópezFarjeat. Paris 59-81.

Bobzein, S. 1998. Determinism and Freedom in Stoic Philosophy. Oxford.

Charles, D. 1984. Aristotle's Philosophy of Action. London.

Cook, M. 2003. Forbidding Wrong in Islam. Cambridge.

Coope, U. 2010. “Aristotle". In A Companion to the Philosophy of Action. Eds. T. O'Connor/ C. Sandis. Chichester, 439-446.

Davidson, H. 1992. Alfarabi, Avicenna, and Averroes on Intellect: The Cosmologies, Theories of the Active Intellect, and Theories of Human Intellect. Oxford.

Druart, T.-A. 1992. “Al-Farabi, Emanation, and Metaphysics”. In Neoplatonism and Islamic Thought. Ed. P. Morewedge. Albany, 127-148.

-. 2006. "Al-Ghazālī’s Conception of Agent in the Tahäfut and the Iqtiṣād: Are People really Agents". In Arabic Theology, Arabic Philosophy, From the Many to the One: Essays in Celebration of Richard M. Frank. Ed. J. E. Montgomery. Leuven, 127-148.

Al-Fārābī 1985. On the Perfect State (Mabādi'ārā'ahl al-madīnat al-fäḍilah). Ed./trans. R. Walzer. Oxford.

Frank, R. 1992. Creation and the Cosmic System: Al-Ghazālī and Avicenna. Heidelberg. Frede, M. 2011. A Free Will: Origins of the Notion in Ancient Thought. Ed. A. A. Long. Berkeley. Gardet, L. 1951. La pensée religieuse d'Avicenne. Paris.

-. 1999. "L'humanisme Gréco-Arabe: Avicenne". Journal of World History 2, 812-34.

Al-Ghazālī 2000. On the Incoherence of the Philosophers. Ed./trans. M. E. Marmura. Provo.

Gilson, É. 1955. History of Christian Philosophy in the Middle Ages. London.

Gimaret, D. 1990. La doctrine d'al-Ash'ari. Paris.

Goichon, A.-M. 1937. La distinction de l'essence et de l'existence d'après Avicenne. Paris.

-. 1938. Lexique de la Langue Philosophique d'Ibn Sīnā. Paris.

Goodman, L. E. 2006. Avicenna (updated edition). Ithaca.

Hasnawi, A. 2001. "La definition du mouvement dans la Physique du Šifā' d’Avicenne”. Arabic Science and Philosophy 11, 219-55.

Hourani, G. F. 1971. Islamic Rationalism: The Ethics of 'Abd al-Jabbār. Oxford. 
Hourani, G. F. 1985. Reason and Traditional Islamic Ethics. Cambridge.

Inati, S. C. 2000. The Problem of Evil: Ibn Sinnā's Theodicy. Binghamton.

Ivry, A. 1984. "Destiny Revisited: Avicenna's Concept of Determinism”. In Islamic Theology and Philosophy: Studies in Honor of George F. Hourani. Ed. M. E. Marmura. Albany, 160-171.

Janssens, J. 2006a "Creation and Emanation in Ibn Sīnā". In Ibn Sīnā and his Influence on the Arabic and Latin World. Ed. J. Janssens. Burlington, ch. IV. Originally published in Documenti e Studi sulla Tradizione Filosofica Medievale 8 (1997), 455-477.

-. 2006b. "The Problem of Human Freedom in Ibn Sīnā". In Ibn Sīnā and his Influence on the Arabic and Latin World. Ed. J. Janssens. Burlington, ch. III. Originally published in Actes del Simposi Internacional de Filosofia de l'Edat Mitjana: El pensament anthropològic medieval en els ambits islàmic, hebreu I cristià. Ed. P. Llorente et al. Vic: Patronat d'Estudis Osonencs, 1996, 112-118.

Kafrawi, S. 2007. "What Makes the Efficient Cause Efficient? The Notion of Will in Ibn Sīnā's Emanative Scheme". Proceedings of the American Catholic Philosophical Association: Freedom, Will, and Nature 81, 179-91.

Kalin, I. 2010. "Will, Necessity and Creation as Monistic Theophany in the Islamic Philosophical Tradition". In Creation and the God of Abraham. Ed. D. B. Burrell/C. Cogliati/J. M. Soskice/W. R. Stoeger. Burlington, 107-132.

Kaukua, J. 2007. Avicenna on Subjectivity: A Philosophical Study. Jyväskylä.

Leaman, O. 1999. A Brief Introduction to Islamic Philosophy. Cambridge.

López-Farjeat, L. X. 2007. "Determinism and Free Will in Alexander of Aphrodisias and the Arabic Tradition”. Proceedings of the American Catholic Philosophical Association: Freedom, Will, and Nature 81, 161-77.

Marmura, M. E. 1984. “The Metaphysics of Efficient Causality in Avicenna (Ibn Sīnā)”. In Islamic Theology and Philosophy: Studies in Honor of George F. Hourani. Ed. M. E. Marmura. Albany.

-. 1994. "Ghazâlī’s Chapter on Divine Power in the Iqtișād". Arabic Sciences and Philosophy 4, 279-315.

McGinnis, J. 2006. "A Medieval Arabic Analysis of Motion at an Instant: The Avicennan Sources to the forma fluens/fluxus formae Debate". British Journal for the History of Science 39: 189-205.

-. 2008. “Avicenna's Naturalized Epistemology and Scientific Method”. In The Unity of the Science in the Arabic Tradition. Eds. S. Rahman/T. Street/H. Tahiri. Dordrecht, 129-152.

-. 2010. Avicenna. Oxford.

-. 2012. "Making Something out of Nothing: Privation, Possibility and Potentiality in Avicenna and Aquinas". The Thomist 76, 551-75.

Michot, Y. 1986. La destinée de l'homme selon Avicenne. Louvain.

Proclus. 2001. On the Eternity of the World (De aeternitate mundi). Ed./trans. H. Lang/A. D. Macro. Berkeley.

Rashed, M. 2000. “Théodicée et approximation: Avicenne”. Arabic Sciences and Philosophy 10: 223-57.

Rist, J. M. 1967. Plotinus: The Road to Reality. Cambridge.

Rudolph, U. 1997. Al-Maturidi und die Sunnitische Theologie in Samarkand. Leiden.

Sorabji, R. 1980. Necessity, Cause, and Blame: Perspectives on Aristotle's Theory. Ithaca.

Watt, W. M. 1971. The Formative Period of Islamic Thought. Oxford. 
Wisnovsky, R. 2000. “Notes on Avicenna’s Concept of Thingness (Šay’iyya)”. Arabic Sciences and Philosophy 10, 181-221.

-. 2002. "Final and Efficient Causality in Avicenna's Cosmology and Theology". Quaestio 2, 97-123.

-. 2003. Avicenna's Metaphysics in Context. Ithaca.

Wolfson, H. A. 1976. The Philosophy of the Kalām. Cambridge.

Zedler, B. H. 1948. "Saint Thomas and Avicenna in the 'De Potentia Dei'”. Traditio 6, 105-59. 